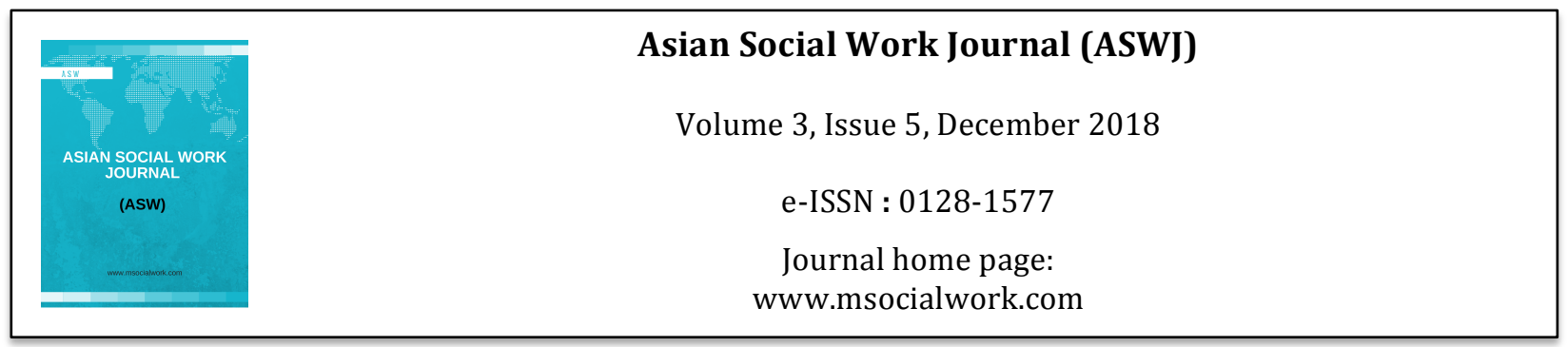

\title{
The Role of Social Work in the Context of Refugess and Asylum Seekers Rights in Indonesia
}

\author{
Alamsyah Agus ${ }^{1}$, Intan Slipi Lia², Muh. Akbar ${ }^{3}$ \\ ${ }^{1}$ School of Social and Behavioral Sciences, Nanjing University, China \\ 2Yayasan Sayangi Tunas Cilik Partner of Save the Children \\ 3Bandung College of Social Welfare, Indonesia \\ Corrrespondence: Alamsyah Agus (shizensyah@gmail.com)
}

\begin{abstract}
The plight of refugees and asylum seekers has been a trending issue of critical importance for social workers in Indonesia. At the end of February 2018, the public was overwhelmed by mass media coverage of a large number of refugees living on the streets in front of the Immigration Office in Jakarta. Their existence needs to be noticed by the government in particular and all parties in general, as it may create a new social problem. Many of the difficulties experienced by them, but the most felt is due to the issue of legal status and language barrier; they can not access public services such as healthcare, education, work, and others. Social workers work to uphold the dignity of all those refugees and asylum seekers including unaccompanied minors (UAM) and to work with them for successful social functioning. This paper explores available integrative literature, quantitative document analysis, and presents mixed methodology through individual interviews and an exploratory study to analyze social workers' role to respond the various issues faced by today's refugees and asylum seekers rights as well as potential way for being supporting document as a policy framework for Indonesian government to ratify the 1951 Refugee Convention.
\end{abstract}

Key words: refugees, asylum seekers, social worker, unacommpanied minor, social functioning, social problem

\section{Introduction}

The situation of refugees and asylum seekers recently has become a significant issue for Indonesia. Based on UNHCR Global Trends (2016), as many as 22.5 million refugees and asylum seekers migrate to various countries including Indonesia. Factors that have contributed to global migration include many things. The reasons why they want to resettle is because of fleeing persecution, conflict, war, or violence in home countries. They are seeking a job or educational opportunities and some of them would like to reunite with their family members. However, historically the chances of refugees ever being resettled are only around 1 percent.

History of refugees in Indonesia began in 1979, as many as 170.000 refugees by setting up camps in Galang Island, Kepulauan Riau. Nowadays, there are 6.191 asylum seekers and 8.279 refugees were registered cumulatively at UNHCR located in Jakarta, according to UNHCR, Afghanistan and Pakistan are the majority, and some of them are from Sri Lanka, Iraq, Iran, Myanmar, and other countries (UNHCR 2016, p. 1). One-third of the total 14.470 are living independently without any assistance. 
Despite the high volume of refugees and asylum seekers heading to the territory of Indonesia for transit, the government has not ratified the 1951 Refugee Convention relating to the legal mechanism to take an active and significant role regarding the status of refugees or asylum seekers in Indonesia. The condition leads to a dilemma for those who are intentionally or unintentionally stranded in Indonesia, and also for the image of government. Many refugees and asylum seekers tend to live with limited privileges, rights, and freedoms until they get legal status from the host country (George, 2012).

Social workers are at the frontline of social services to vulnerable groups in global societies for dealing with trans-cultural problems (Hessle, 2007). The new social work workforce is oriented with adequate knowledge, skills, and values for working effectively with refugees and asylum seekers.

Therefore, this paper will seek to explore available integrative literature, quantitative document analysis, and provide combined methodology through semi-structured interviews and an exploratory study of the role of social workers in responding to the issues of refugees and asylum seekers rights in Indonesia. This essay will address three significant areas of concern: Legal Rights, Detention, and Biological, Psychological, Social and Spiritual (BPSS) Aspects. We also present a conceptual framework for supporting a document to be addressed by the Indonesian government to ratify the 1951 Refugee Convention

\section{Problems of Refugees and Asylum Seeker in Indonesia}

Most refugees, asylum seekers, and UAM have difficulty to directly move to get permanent resettlement because the mostly unplanned and unanticipated nature of the move and the unexpected circumstances which precipitate the movement. In this context, the role of transit country in global migrations increases due to the process can go on for a while and pass through specific locations whether it is planned or not before they are able to reach their final destination. During this time, refugees and asylum seekers in Indonesia face an intersecting web of social problems, including;

\section{Legal Rights}

The main problem of these refugees and asylum seekers is their legal status. The root of this problem grows significantly; it evolves touching many aspects of their lives. Asylum seekers and refugees consisting of families with children, a single young man or woman, including unaccompanied children have become a new social problem in Indonesia. They live on the margins of society, fearful of arbitrary harassment, extortion, arrest, and detention. Some of them are homeless because of inadequate shelter, unable to work to fulfill their needs, and access the free health care. Not many schools also can accept them to learn because of the language barrier and unqualified teachers, not to mention psychosocial problems caused by the trauma of torture or feelings desperately need to be handled over which happened in their home country before coming to Indonesia.

Despite all the limitations, they come to other countries to seek protection and asylum. Heading to Indonesia or some other countries for transit, they really hope that they will be able to settle in a country and continue their dreams and life. There are definitely human rights embedded in them wherever they are as a universality. They just want to live like human being, gain freedom, and feel happiness as well.

\section{Detention Condition}

Nowadays, Indonesia has 13 detention centers across Indonesia's archipelago to facilitate and accommodate refugees and asylum seekers including UAM. The amount is actually inadequate considering that around thousands of asylum seekers and refugees have illegally entered in territory of Indonesia. For example, the Immigration Detention Center in Kalideres Jakarta has a maximum capacity of 120, but it currently houses 155 asylum seekers, 69 refugees and a handful of foreigners who had overstayed their visa. It is meant to hold only foreign nationals who have violated visa regulations or who are to be deported. It can take a long time for asylum seekers to get resettlement in a 
new country once they have registered with the local UNHCR office, the fastest in four years according to the agency's records and many of them succumb to the harsh conditions of living in transit. Some asylum seekers and refugees in Indonesia have now sought shelter at immigration detention centers, including one in Kalideres in the west of the capital Jakarta. These immigration detention centers are meant for foreign nationals who violate Indonesia's immigration laws. Nevertheless, the centers have opened their doors to asylum seekers and refugees, but they are fast running out of space.

Refugees and asylum seekers are typically kept in locked cells and given inhumane treatment from detention center officer (Missbach \& Sinanu, 2013). Health and sanitation conditions are deplorable, and the medical team tends to be slow in responding to their health issues (Human Rights Watch, 2013). Many refugees in Indonesian detention centers are getting stress because of locked up for long hours, away from beloved families, poor living conditions, lack of amusement and waiting for the long process of their asylum claim to UNHCR.

Also intermingling between them and also illegal immigrant in the same detention center may spark conflict. For instance, in Medan detention center has happened a conflict raising from over-capacity and tempering between them which caused 8 Rohingyas died. Inadequate capacity and people being prone to conflict are one of indications that the right to safety in detention center is not optimal. Whereas, according to the Law No. 39 of 1999 on Human Rights in Article 30 stipulates that "everyone has the right to safety" in which the word "everyone" means protection over the right to safety provided by the Government of Indonesia which covers everyone including these refugees, asylum seekers, and UAM within the Indonesian territory.

One of the unaccompanied children who had lived in the shelter in Jakarta, Shafee told the story of his experience while he was living in one of the detention houses in Tanjung Pinang before being transferred to the shelter. He said that he did not get sufficient food while he was there and felt uncomfortable. He had to sleep together with other refugees in one room, have nothing to do, just sleep, occasionally chatted with other fellow refugees, even he just sat silently a whole day for looking at the situation that happened inside the detention house while thinking of his fate.

\section{Biological, Psychological, Social and Spiritual (BPSS) Aspects}

Through the handling process of refugees and asylum-seekers, some issues will surface to their core concerns as well as biological, psychological, social and spiritual aspects. Refugees and asylum seekers lose their livelihood, their homes, and are forced into poverty, which will affect their mental health and well-being (Palmer, 2007).

Galambos (2005) mentions that refugees, asylum seekers, or Internally Displaced People (IDPs) tend to experience the loss of family connections, colleagues, long-standing social contacts, overall support and social relationship emotionally. Also, they suffer from psychosocial problems such as intermittent explosive disorder that characterize the experience of those who are secondary victims to the loss (George, 2012).

Limitations on those aspects have an impact on their unfocused spiritual activities, sterile shelter environments and the inability to socialize with local communities causing difficulties in worship.

These problems are much better dealt with within the context of the community itself, rather than the artificial environment of the courts (Ife, 2006). This means that community acceptance can be obtained through the role of social workers who are tasked with understanding local communities of the refugees and asylum seekers. Therefore, humanitarian services within which there are social workers represent an important aspect of community development in this case the social functioning of refugees and asylum seekers through the advocacy roles of central government, local government and stakeholders. 


\section{The Role of Social Workers in Concern for Successful Social Functioning}

Professionals in the human services field specify that refugees and asylum seekers need long-term recovery mental health interventions such as family counselling, individual or group therapy, and learning relaxation techniques (Boisvert, 2006). By providing these basic needs, especially in the areas of safety, health care, education, food, and most importantly the provision of psychosocial support, their overall well-being might be improved enormously (Kim, Torbay, \& Lawry, 2007).

As social workers are definitely seeing these asylum seekers and refugees is part of a social being that also has the role and social function in personal life. They have own problems that disrupt their social functioning. These refugees are usually confused in identifying the needs and problems faced with too much. Therefore, social workers help them to be able to determine which problems and needs are priorities.

In this context, social workers need to improve the capacities to handle and to care for all refugees and asylum seeker including unaccompanied minors. Social work as a profession has much to offer in services for them. Social workers can absolutely respond to the complex needs of them within an understanding of the broader context of the social welfare system and dynamics of interconnected relationship.

Social workers who specialize in working with communities and individuals of refugees, asylum seekers, or even UAM can alleviate some of these challenges by offering support, counseling and advocacy for connecting them to valuable resources.

For example, one of the common issues is about the client's status. In this case, social workers may collaborate with legal professionals. Their role tend to include gathering important documents, writing detailed reports that can support their client's case, and serving as a primary contact and advocacy to law enforcement officials.

Social workers may also work with newly arrived refugees and asylum seekers by facilitating the moving process to their new surroundings. This may include supporting clients through social services, job placement assistances, language courses, cultural orientations, and so on.

Also, for those who escaped hostile environments or have experienced traumatic events in their home country may need specialized counseling. Social workers may offer therapy and trauma healing which can help them to recover and move forward with their lives.

The values of social work, acknowledging the principles of both social justice and the dignity of human being, likewise to pay more attention to the importance of ensuring that responses to successful social functioning. The concept of social functioning is a tool for understanding the unique focus of social work through the process of change and distinguishing social work from the other related professions.

The successful social functioning is a person's ability to accomplish those tasks in many situational context and to fulfill his or her basic needs, such as having food, shelter, and medical care. Along with being able to protect oneself from harm, finding healthy relationship and social support, having meaning and purpose in life, and also enable to perform his or her major social roles in their community. (NASW, 1999).

Trends in global migration and current patterns of settlement tend to be complicated, dynamic, and reflect different characteristics related to the histories of the countries as well as more recent geopolitical and economic pressures (Castles, 2000). In Indonesia, the situation is very political and the authority is left entirely to the destination country or related parties to take care of them. In this case, social workers begin to become a facilitator for them to provide information, give understanding regarding the problem, explore their potential, and work together to find solutions. 
Social workers can also lead refugees and asylum seekers to see other problems such as access to education or job skills. They asked to learn how to accustomed to living in Indonesia by studying the language, volunteering or seeking education in local schools. One of the most recurring roles of social workers is as a motivator. Social workers should be able to encourage, motivate and create a passion for getting better and convincing them of their abilities. Some refugees who are quite right in Indonesian can be an interpreter in some schools for fellow refugees or they are paid professionally or just voluntarily. They are not allowed to work in Indonesia, but by doing such activity may help them to survive.

Related to the health problems or other service access, social workers play the role of a broker. The process of connecting people with institutions or stakeholders which have resources or providing information on accessing services required. Social workers made some efforts to collaborate with Puskesmas (community health services), public hospital, and linked to further health information. The refugees and asylum seekers register by showing the identity card from UNHCR. They get medicine and other facilities just like the local community. Also, social workers connect them to other public services as needed.

Based on interviewed with one Afghanistan refugee name is Hamed who is looking forward to getting resettlement to the United States of America. His hobby the is reading, and he is excited when a social worker accompanied him to go to one of the university's libraries near from his shelter so then he can go there every day. Although he does not have access to borrow books because he does not have an official ID but is keen on reading the books there, it is perfect for him because he can indirectly interact with students in the library.

The ability to show empathy needs to be trained because what we know from the mass media (e.g., newspapers, radio, television) about the conflict happens in their country is only a small snapshot of the actual situation. One of the unaccompanied children in a part of counseling sessions responded by retelling his story that happened in his country every day. He and his family could be the one who died. It can be seen from his expression that he is angry and afraid while telling her story. Hence, we need to be a good listener and show our sincere empathy to them since we could never know what he and the other refugees and asylum seekers had been through in their home country.

This study emphasizes the role of social in clinical practice especially for unaccompanied minor (UAM) also known as separated children. Their experiences are characterized by trauma, loss, and separation which in turn is connected with potential emotional problems (Hodes et al., 2008). UAM are at high risk of mental distress, particularly post-traumatic stress disorder (Hodes, 2000).

Uncertainty about the future is considered to have a significant impact on the well-being of UAM. In this regard, negotiating a complex asylum system and adapting to a new 'way of life' have also emerged as significant psychosocial challenges for UAM (Kohli, 2011). Therefore, social workers must response following best practices, including culturally competent services, community integration, support, and advocacy to build the frameworks for change.

\section{Policy and Program for Refugees and Asylum Seeker in Indonesia}

Ratifying the 1951 Refugee Convention then becomes one issue for the Government of Indonesia. There are thousands of asylum seekers in Indonesia who have not acquired the status of refugee to obtain the rights guaranteed in the 1951 Convention, because ofthe complexity of determining their status, as conducted by UNHCR. These people do not have any job, any clear status, nor any residence in Indonesia. They are living dependently with the assistance of the Government of Indonesia and may be burdening the State's budget. Hence, ratifying the 1951 Convention has become one particular issue to rectify this situation.

Since Indonesia is not a party to the 1951 Refugee Convention and also the 1967 Protocol, Indonesia does not render formal rights to refugees and asylum seekers within its territory. Indonesia merely 
provides "tolerance" for their presence under UNHCR. Moreover, Indonesia does not have internal mechanisms to process asylum claim or to accommodate resettlement and ensure fair access forshelter and asylum to those in need. However, Indonesia is bound to the principle of non-refoulement (prohibition to return) contained in Article 33 of the 1951 Refugee Convention as a customary international law applicable to refugees, asylum seeker, or those who need some form of shelter from the State authority which has control over them.

The ratification of 1951 Convention is considered as one solution to regulate the refugees. But this issue has also created some controversies. Some argue that Indonesia should ratify this convention, on the other hand, others argue that ratifying this convention will only gain more problems in Indonesia.

First, ratifying the 1951 Refugee Convention will help Indonesia to have a precise mechanism on overcoming the refugee status. A person should acquire refugee status To obtain the refugee status from the 1951 Convention. By ratifying the Convention and its Protocol, Indonesia will be able to exercise its jurisdiction by imposing the applicable national law and deciding the status of the refugees, so Indonesia can directly contribute and get involved in settlement of the refugee problems. Indonesia will also have clear obligations and mechanisms on coping with the refugees' problems by becoming the Contracting State. Therefore, the problematic device will be solved.

Ratifying the 1951 Convention will also be a form of fulfillment of Indonesia's obligation as a member of United Nations. It has been Indonesia's obligation to enforce the human rights protection and the legitimate national interest to maintain control of national borders. It is a form of manifestation of the Universal Declaration of Human Rights and the Law No. 39 of 1999 on Human Rights. Furthermore, Indonesia has included the ratification of the 1951 Convention on its National Action Plan for Human Rights 2015-2019 through Presidential Decree No. 75 of 2010; it is only about the implementation of the Law to fulfil its obligation.

Indonesia can boost its image as a country that promotes Human Rights and the implementation of the Universal Declaration of Human Rights by being a part of the 1951 Convention. This action will make friendlier ties among nations. However, ratifying these instruments may only gain more problems in Indonesia. The current issues about the welfare, education, religious sentiment, and protection of the Indonesian people has not been resolved and handled correctly. Indonesia has to consider its capacity to protect its people first before other nationalities. On foreign relations, Indonesia has to regard its national interest as stated on Article 3 of Law No. 37 of 1999 that foreign policy adheres to the principle of free and active but prioritizes national attention.

People also argue that by ratifying the 1951 Refugee Convention, it means Indonesia is welcoming the refugees to stay. Inviting the refugee to stay means that the government has to prepare a certain amount of budget for the refugees. By 2014, Indonesia has spent USD 8,146,793 or about 110 billion Rupiah. This amount of money could be allocated to carry out Indonesia's welfare program. Although Indonesia is the largest economy in South East Asia and a member of the G-20, approximately $40 \%$ of the entire population live below the poverty line with limited employment opportunities (Handayani 2012). Health insurance and higher education are mostly unaffordable for under privileged people. Meanwhile, Indonesia is developing rapidly, its economic growth, infrastructure development, and social assistance program related to education and health care are overshadowed by the public need (OECD 2015).

There are many avenues which social work practitioners can help shape policy regarding social services and resources for refugees and asylum seekers. Of the most prominent, social workers should get involved in advocacy and policy change on behalf of those who get accessibility problems because their circumstances (Delgado, Jones, \& Rohani, 2005). Mosley (2014) argues that social workers can take an action to procure resources and improve policies through advocacy.

In advocacy, social workers need to improve the knowledge of community about the issues facing refugees. Convincing interested stakeholders to assist these refugees and asylum seekers is not as easy. 
To raise awareness to the public for seeing their rights as human beings, also does not discriminate against them because of illegal status.

It is definitely clear that action needed to get people's attention towards an issue, and to control policy makers to find a solution. The advocacy efforts will exemplify and deepen social work's commitment to social justice and human rights for those who the most vulnerable in society, such as children, women and the elderly.

Social workers definitely have an important role to work with the community and minimize the impact of Indonesia has not ratified the 1951 Refugee Convention yet. The opportunity of refugees, asylum seekers, and also unaccompanied minors (UAM) resettled into a third country will always exist, and most importantly they do not lose hope of it.

\section{Recommendations for Indonesian Government Towards Ratification of the 1951 Refugee Convention}

In this paper, we want to explore more deeply how the roles that social workers can play in addressing the issues related to refugees and asylum seekers' rights in Indonesia, another thing that social workers need to concern to the level of acceptance the community against these refugees if Indonesia participates in ratification. Based on a survey released by Amnesty International in 2016, Indonesia was among the countries considered unfriendly to refugees from 27 countries surveyed. Indonesia was ranked $26^{\text {th }}$ and Russia was ranked $27^{\text {th }}$. On the other hand, China was in first place, followed by Germany and Britain was in the second and the third place regarding the public acceptance of refugees.

We would like to recommend some notes to the government of Indonesia to be able to do many things to help the refugees and asylum seekers. But it will be difficult to achieve it as long as Indonesia has not ratified 1951 refugee convention. This condition obviously contrasts with the Indonesian government afford to encourage the creation of "the fair and civilized values of humanity" as one of the foundations of the Indonesian state. However, no one denying that there were a few parties who began to bring religious sentiments to address the existence of these refugees and asylum seekers.

As social workers, we see that hard work from all stakeholders is really needed to give understanding for community. Mostly community thinks that by providing assistance to refugees and asylum seekers, it is more than enough, while it is only short-term and does not touch their root problem. Social workers have an important role to work with the community, not only with individual refugees to contribute in influencing the creation of community acceptance but also minimizing the impact of the refugee policy. Their expectation to the option of resettle in the third countries will never get lost.

Indonesia should determine its position in responding to the current refugees and asylum seekers who continue to make Indonesia as a destination country. By taking steps to ratify the 1951 Refugee Convention to provide the Indonesian Government with greater opportunity to be directly involved and contribute in accordance with national interests in the handling of refugees and asylum seekers, decisions about refugee status are no longer dependent on UNHCR's decision.

In addition, ratification also provides an opportunity for Indonesian Government to obtain international assistance and cooperation related to strengthening national capacity in handling refugees and asylum seekers. International cooperation will encourage some resolutions of the problem of refugees and asylum seekers in more comprehensive way.

Thus, the burden of handling refugees and asylum seekers is not borne solely by our government, but also the support of the international community which is engaged in the issue of refugees and asylum seekers.

Indonesian government will have the authority to make regulations on clear boundaries to be able to distinguish those who can become a citizen and who cannot become a citizen. The ones who are 
qualified to be a citizen are required to integrate locally and assimilate with the local people and to be sanctioned in violation under applicable law as well as existing social norms.

It is also definitely an obligation of Indonesia to treat the refugees and asylum seekers is the same position as other Indonesian citizens. The available options are voluntary repatriation to be taken considering that resettlement in Indonesia as a long-term solution is not achieved or deported. Thus, Indonesia has provided 'legal ways' for these refugees to start their new lives and not to do 'smooth ways' to accommodate them but the uncertainty of their citizenship status so they cannot earn a decent living as their rights in Indonesia.

The next recommendation is the establishment of an area that allows several countries to assist each other in handling refugees who transit to arrive in a third country. We call this a sister state, in which two or more countries cooperate and do not charge of a single country for asylum, but it is the environmental responsibility of those countries in the event of Australia, the United States, Germany and most countries in Western Europe restricted their borders for refugees and asylum seekers.

Several articles and instruments of 1951 Refugee Convention also need to be assessed for its standard, especially for developing countries such as Indonesia, as the per head index for refugees defined by UNHCR is very high and should be in line with State Budgets (APBN) and local wisdom in Indonesia. It should be of UNHCR concern or a review of the 1951 Convention to conform to the contemporary issues related to refugees.

Indonesian government's attention to refugees and asylum seekers does not mean ignoring the domestic obligations of Indonesia but always combined with the international responsibility that still upholds Human Rights. In that way, we totally believe that it will result in social justice for society.

\section{Conclusion}

Social workers are seeing refugees and asylum seekers are part of a social being that also has the role and social function in personal life. They have problems which disrupt their social activities. These refugees and asylum seekers are usually confused in identifying the needs and difficulties. Therefore, social worker plays a crucial role in helping the asylum seekers and refugees to uphold and protect their rights to get freedom of movement, housing, education, justice, lawful employment, integrating into their host communities, and so forth.

This paper is a form of encouragement and support to Indonesian policy frameworks to participate in promoting recognition and encouraging the legal framework of refugee protection by ratifying the 1951 Refugee Convention with one of the Indonesian State Philosophy "Pancasila" that upholds the fair and civilized values of humanity.

\section{References}

Amnesty International Report 2017/2018. (2018). The State of The world's Human Rights. London: Amnesty International.

Boisvert, D. (2006). Healing the silent agonies of the earthquake. Migration.

Castles, S. (2000). Ethnicity and Globalisation. London: Sage.

Deklarasi Umum Hak Asasi Manusia (DUHAM), 17 (TAP MPR 1998).

Delgado, M., Jones, K, \&Rohani, M. (2005). Social work practice with refugee and immigrant youth in the United States. BostonP: Pearson Education, Inc.

Galambos, C. (2005). Natural disasters: Health and mental health considerations. Health and Social Work.

Handayani, I P. 2012, February 13. Beyond statistics of poverty. Retrieved April 20, 2018, from Jakarta Post: http:/www.thejakartapost.com/news/2012/02/13/beyond-statistics-poverty.html 
Hessle, S. (2007). Social Work as a Profession- a comparative cross-national perspective. Birmingham: IASSW/Venture Press.

Hodes, M. (2000). Psychologycally distressed children in UK. Psychology and Psychiatry Review.

Hodes, M., Jagdev, J. Chandra, N, \&Cunnif, A. (2008). Risk \& Resilience for psychological distress amongst unaccompanied asylum-seeking adolescents. The Journal of Child Psychology\& Psychiatry, 723-732.

Human Rights Watch. (2013). Barely Surviving, Detention, Abuse and Neglect of Migrant Children in Indonesia. Retrieved April 12, 2018, from Human Rights Watch: https:/www.hrw.org/report/2013/06/23/barely-surviving/detention-abuse-and-neglect-migrantchildren-indonesia

Ife, J., Frank Tesoriero. (2006). Community development: Community-Based Alternatives in an age of Globalization (3rd. ed.). Sydney: Pearson Education Australia.

Indonesia: "Regulation of the President of the Republic of Indonesia No.125 the year 2016 Concerning the Handling of Foreign Refugees. (2016, December 31). Retrieved April 24, 2018, from http;//www.refworld.org/docid/58aeee374.html

IOM. (2014). Akomodasi Non-Detensi IOM Indonesia. Retrieved April 19, 2018, from IOM Indonesia: http://www.iom.or.id/sites/default/files/News-September-INDzpo7_0.pdf

Kim, G, Torbay, R, \& Lawry, L. (2007). Basic health, women's health, and mental health among internally displaced persons in Nyala province South Darfur, Sudan. American Journal of Public Health, 353-361.

Kohli, R. (2011). Working to ensure safety, belonging and success for unaccompanied system asylumseeking children. Child Abuse Review , 311-323.

Missbach, A. (2013). Waiting on the islands of 'Stuckedness' Managing Asylum seekers in Island Detention camps in Indonesia: From the late 1970s to the early 2000s. ASEAS-Austrian Journal of South-East Asian Studies, 6, 281-306.

Mosley, J. (2014). From skid row to the statehouse: How nonprofit service providers overcome barriers to political advocacy involvement. Baltimore: Johns Hopkins University Press.

National Association of Social Workers. (1999). Code of Ethics. Washington DC: NASW.

Organisation for Economic Co-operation adn Development (OECD 2015). 2015. OECD Economic Surveys Indonesia 2015. Paris: OECD Publishing.

Stoyanova, Vladislava. (n.d.). The Principle of Non-Refoulement and the Right of Asylum-Seekers to Enter State Territory. Interdisciplinary Journal of Human Rights Law, 1-11.

UN General Assembly. 1951. Convention relating to the status of refugees. United Nations Treaty Series.

Undang-Undang Dasar Negara Republik Indonesia (1945).

Undang-Undang tentang Hak Asasi Manusia, 165 (1999).

UNHCR . 2016. Indonesia Fact Sheet. Retrieved May 4, 2018, from UNHCR Jakarta: http://www.unher.org/50001bda9.pdf

UNHCR. 2015. Global Appeal 2016-2017. Retrieved May 4, 2018, from UNHCR: http://www.unhcr.org/pages/49c3646c4b8.html 